The University of Southern Mississippi

The Aquila Digital Community

Faculty Publications

$1-1-2014$

\title{
Importation of Exotic Ticks and Tick-Borne Spotted Fever Group Rickettsiae into the United States by Migrating Songbirds
}

\author{
Nabanita Mukherjee \\ University of Southern Mississippi, nabanita.mukherjee@eagles.usm.edu \\ Lorenza Beati \\ Georgia Southern University \\ Michael Sellers \\ University of Southern Mississippi, johnny.sellers@usm.edu \\ Laquita Burton \\ Georgia Southern University \\ Steven Adamson \\ University of Southern Mississippi, Steven.Adamson@usm.edu
}

See next page for additional authors

Follow this and additional works at: https://aquila.usm.edu/fac_pubs

Part of the Biology Commons

\section{Recommended Citation}

Mukherjee, N., Beati, L., Sellers, M., Burton, L., Adamson, S., Robbins, R. G., Moore, F., Karim, S. (2014). Importation of Exotic Ticks and Tick-Borne Spotted Fever Group Rickettsiae into the United States by Migrating Songbirds. Ticks and Tick Borne Diseases, 5(2), 127-134.

Available at: https://aquila.usm.edu/fac_pubs/8849

This Article is brought to you for free and open access by The Aquila Digital Community. It has been accepted for inclusion in Faculty Publications by an authorized administrator of The Aquila Digital Community. For more information, please contact Joshua.Cromwell@usm.edu. 


\section{Authors}

Nabanita Mukherjee, Lorenza Beati, Michael Sellers, Laquita Burton, Steven Adamson, Richard G. Robbins, Frank Moore, and Shahid Karim 


\title{
Importation of exotic ticks and tick-borne spotted fever group rickettsiae into the United States by migrating songbirds
}

\author{
Nabanita Mukherjee ${ }^{\mathrm{a}}$, Lorenza Beati ${ }^{\mathrm{b}}$, Michael Sellers ${ }^{\mathrm{a}}$, Laquita Burton ${ }^{\mathrm{b}}$, Steven Adamson ${ }^{\mathrm{a}}$, \\ Richard G. Robbins ${ }^{\mathrm{c}}$, Frank Moore ${ }^{\mathrm{a}}$, and Shahid Karim ${ }^{\mathrm{a},{ }^{*}}$ \\ aDepartment of Biological Sciences, University of Southern Mississippi, Hattiesburg, MS 39406, \\ USA \\ 'Institute of Coastal Plain Sciences, Georgia Southern University, Statesboro, GA 30458, USA \\ ${ }^{\mathrm{C}}$ Armed Forces Pest Management Board, Office of the Deputy Under Secretary of Defense for \\ Installations and Environment, Building 172, U.S. Army Garrison Forest Glen, Silver Spring, MD \\ 20910, USA
}

\section{Abstract}

Birds are capable of carrying ticks and, consequently, tick-transmitted microorganisms over long distances and across geographical barriers such as oceans and deserts. Ticks are hosts for several species of spotted fever group rickettsiae (SFGR), which can be transmitted to vertebrates during blood meals. In this study, the prevalence of this group of rickettsiae was examined in ticks infesting migratory songbirds by using polymerase chain reaction (PCR). During the 2009 and 2010 spring migration season, 2064 northward-migrating passerine songbirds were examined for ticks at Johnson Bayou, Louisiana. A total of 91 ticks was removed from 35 individual songbirds for tick species identification and spotted fever group rickettsia detection. Ticks were identified as Haemaphysalis juxtakochi $(\mathrm{n}=38,42 \%)$, Amblyomma longirostre $(\mathrm{n}=22,24 \%)$, Amblyomma nodosum $(\mathrm{n}=17,19 \%)$, Amblyomma calcaratum $(\mathrm{n}=11,12 \%)$, Amblyomma maculatum $(\mathrm{n}=2,2 \%)$, and Haemaphysalis leporispalustris $(\mathrm{n}=1,1 \%)$ by comparing their $12 \mathrm{~S}$ rDNA gene sequence to homologous sequences in GenBank. Most of the identified ticks were exotic species originating outside of the United States. The phylogenetic analysis of the 71 ompA gene sequences of the rickettsial strains detected in the ticks revealed the occurrence of 6 distinct rickettsial genotypes. Two genotypes (corresponding to a total of 28 samples) were included in the Candidatus Rickettsia amblyommii clade (less than 1\% divergence), 2 of them (corresponding to a total of 14 samples) clustered with Rickettsia sp. "Argentina" with less than $0.2 \%$ sequence divergence, and 2 of them (corresponding to a total of 27 samples), although closely related to the $R$. parkeri-R. africae lineage (2.50-3.41\% divergence), exhibited sufficient genetic divergence from its members to possibly constitute a new rickettsial genotype. Overall, there does not seem to be a specific relationship between exotic tick species, the rickettsiae they harbor, or the reservoir competence of the corresponding bird species.

\footnotetext{
(C) 2013 Elsevier GmbH. All rights reserved.

*Corresponding author: Shahid.Karim@usm.edu (S. Karim).

Competing Interests: The authors have declared that no competing interests exist.
}

Publisher's Disclaimer: This is a PDF file of an unedited manuscript that has been accepted for publication. As a service to our customers we are providing this early version of the manuscript. The manuscript will undergo copyediting, typesetting, and review of the resulting proof before it is published in its final citable form. Please note that during the production process errors may be discovered which could affect the content, and all legal disclaimers that apply to the journal pertain. 


\section{Keywords}

SFGRM; Exotic ticks; Tick molecular ecology; Migratory songbirds

\section{Introduction}

Ticks have a diverse range of vertebrate hosts and can acquire and transmit microorganisms while blood feeding. Ticks can transmit pathogens to humans and animals including bacteria, viruses, and protozoans (Sonenshine, 1993). Disease agents can remain in the tick from one life stage to the next (transstadial transmission). Additionally, infected female ticks can also pass pathogenic microbes to the next generation via their eggs (transovarial or vertical transmission) (Burgdorfer and Brinton, 1975).

Rickettsia spp. are obligate intracellular organisms, which are found worldwide and can infect arthropod vectors. They have traditionally been genetically and antigenetically classified into the spotted fever group (SFG) and the typhus group (TG). Several strains of the SFG rickettsiae have been associated worldwide with human disease and are transmitted by ticks (Roux and Raoult, 2000; Labruna et al., 2004).

Migratory birds are known to serve as long-distance carriers for several ectoparasites and microbial agents (Hoogstraal et al., 1961, 1963; Anderson et al., 1986; Olsén et al., 1995, 1998; Palmgren et al., 1997; Bjöersdorff et al., 2001; Scott et al., 2001; Morshed et al., 2005; Santos-Silva et al., 2006; Elfving et al., 2010; Movila et al., 2010; Hildebrandt et al., 2010; Hasle et al., 2011). Birds often serve as hosts of immature ticks and represent a reservoir for human and other animal tick-borne pathogens (Hubalek, 2004).

Millions of songbirds travel long distances between temperate breeding areas in the continental United States and tropical wintering areas in the Caribbean, in Mexico and in Central and South America (Rappole et al., 1995). Migrating songbirds provide a means for ectoparasites, like ticks, to be dispersed across thousands of miles. Several species of ticks of the genus Argas, Ornithodoros, Ixodes, Amblyomma, and Haemaphysalis commonly parasitize birds (Barros-Battesti et al., 2006; Ogrzewalska et al., 2008; Movila et al., 2010; Hasle et al., 2011). However, the literature concerning spotted fever group rickettsial infections of ticks found on northward migrating songbirds in the United States is scant, and the potential role of songbirds as reservoirs or amplifying hosts for exotic spotted fever group rickettsiae has not been studied.

The main objective of this study was to investigate the prevalence of different SFG rickettsial species associated with ticks infesting northward-bound Neotropical-Nearcticmigratory songbirds collected at a Mississippi flyover (LA) using molecular approaches.

\section{Materials and methods}

\section{Study site}

This study was conducted during the spring 2009 and 2010 migration seasons (15 March to 15 May) at a long-term migratory bird study site near Johnson Bayou, Louisiana (29o 45' N, 93o 37'W). Johnson Bayou is comprised of woodlands, known as chenier (French for "oak forest"), along the northern coast of the Gulf of Mexico and migratory birds often stop here to rest and feed following their flight across the Gulf of Mexico (Moore, 1999). The dominant tree species are live oak (Quercus virginiana) and hackberry (Celtis spp.), as well as toothache tree (Aralia spinosa), red mulberry (Morus rubra), and honey locust (Gleditsia triacanthos). Shrubs include yaupon (Ilex vomitoria), sweet acacia (Acacia farnesiana), 
palmetto (Sabal spp.), honeysuckle (Lonicera spp.), poison ivy (Toxicodendron radicans), and greenbrier vines (Smilax spp.).

\section{Bird capture}

Birds were captured ( $\mathrm{n}=2064)$ using nylon mist nets. Captured birds were carefully removed from the nets, and age and sex were determined, when possible (Pyle, 1997). Subcutaneous fat was assessed (Helms and Drury, 1960), each bird was weighed to the nearest 0.1 gram, and a U.S. Fish and Wildlife Service aluminum band was attached. All studies with animals were performed in accordance with a protocol approved by the Institutional Animal Care and Use Committee (IACUC) at the University of Southern Mississippi. An effort was made to sample 10 focal species of migratory birds for ticks based on "foraging cohorts" used to describe standard feeding locations (Barrow et al., 2000). The sub-canopy/canopy group consisted of white-eyed vireos (Vireo griseus), red-eyed vireos (Vireo olivaceus), and scarlet and summer tanagers (Piranga olivacea and P. rubra). The understory group included hooded warblers (Wilsonia citrina), gray catbirds (Dumetella carolinensis), and yellowbreasted chats (Icteria virens). The ground group consisted of wood thrush (Hylocichla mustelina), northern waterthrush (Seiurus noveboracensis), and Swainson's thrush (Catharus ustulatus).

\section{Ticks and bird blood collection}

Birds were examined for attached ticks by blowing on the feathers of the head, neck, breast, and lower ventral surfaces, thereby separating the feathers, and by examining the nape, bill, eyes, wings, and cloaca (Gregoire et al., 2002). When necessary, feathers were parted using forceps or a fine-toothed comb (Kinsey et al., 2000). When a tick was found, it was carefully removed using fine-tipped forceps and placed in $70 \%$ ethanol. The bird species name, band number, tick attachment site, and collection date were documented. Blood samples were taken from the 10 focal species regardless of the presence or absence of ticks to investigate whether tick-borne spotted fever group rickettsiae were present.

\section{Dragging}

Dragging was performed for standardized amounts of time during 2009-2010 springs to estimate the relative abundance of ticks at study sites by the drag-cloth method (Falco and Fish, 1988).

\section{Morphological tick identification}

Collected ticks were identified using the standard morphological keys (Cooley, 1946; Clifford et al., 1961; Keirans and Durden, 1998). Because half of the world's Amblyomma species occur in the Neotropics (Guglielmone et al., 2010) and the preimaginal stages (larva, nymph) of many of these species remain unknown or undescribed, it was often impossible to identify specimens below the genus level.

\section{DNA extraction and nested PCR amplification of spotted fever group rickettsiae}

Genomic DNA was extracted individually from ticks and from bird blood samples using the DNeasy blood and tissue kit (Qiagen, CA), following the manufacturer's protocol for isolation of DNA from animal blood samples. Ticks in $70 \%$ ethanol were individually cut into small pieces with a scalpel and homogenized in $200 \mu \mathrm{L}$ of phosphate buffered saline with a sterile micropestle. The homogenized individual tick tissues were disrupted by passage through a 27 -gauge needle attached to a $1-\mathrm{mL}$ syringe. The extracted genomic DNA was quantified spectrophotometrically using a Nanodrop-100 (Nanodrop Technologies). Identical amounts of tick DNA and bird blood DNA ( $25 \mathrm{ng} / \mu \mathrm{l})$ were used for each PCR reaction (Roux et al., 1996). Spotted fever group rickettsial infection was detected by using 
rickettsial outer membrane protein A (rompA) gene-specific primers in a nested PCR assay (Blair et al., 2004). Briefly, the primers RR190-70 (5'-

ATGGCGAATATTTCTCCAAAA-3') and RR190-701 (5'-

GTTCCGTTAATGGCAGCATCT-3') were used for the primary reaction, and primers 190FN1 (5'-AAGCAATACAACAAGGTC-3') and 190-RN1 (5'-

TGACAGTTATTATACCTC-3') were used for the nested reaction. In the primary reaction, $2.5 \mu \mathrm{L}$ of DNA template $(\sim 62.5 \mathrm{ng}$ ) was added to $12.5 \mu \mathrm{L}$ of $2 \times$ PCR Master Mix (Promega, Madison, WI), $8 \mu \mathrm{L}$ of nuclease-free water, and $1 \mu \mathrm{L}$ of each primer $(10 \mu \mathrm{M})$. In the nested reaction, $12.5 \mu \mathrm{L}$ of $2 \times$ PCR Master Mix was used, $8 \mu \mathrm{L}$ of nuclease-free water, $1 \mu \mathrm{L}$ of each nested primer $(10 \mu \mathrm{M})$, and $2.5 \mu \mathrm{L}$ of the primary PCR reaction. The PCR reactions were performed in a MyCycler Thermal Cycler (Bio-Rad Laboratories, USA) as follows: 1 cycle at $95^{\circ} \mathrm{C}$ for $3 \mathrm{~min}, 35$ cycles of $95^{\circ} \mathrm{C}$ for $20 \mathrm{~s}, 46^{\circ} \mathrm{C}$ for $30 \mathrm{~s}$, and $63^{\circ} \mathrm{C}$ for $60 \mathrm{~s}$, and 1 cycle at $72^{\circ} \mathrm{C}$ for $7 \mathrm{~min}$. For each reaction, 2 negative controls $\left(\mathrm{H}_{2} \mathrm{O}\right.$ and PCR reaction minus gene-specific primers) and one positive control (50 ng of Rickettsia endosymbiont of A. maculatum ompA, GenBank \# JX134638) were included. The amplicons were analyzed with a $2 \%$ agarose gel containing ethidium bromide and observed using a UV transilluminator. After electrophoresis, PCR products of $540 \mathrm{bp}$ were excised from the gel, and DNA was extracted using a QIAquick DNA gel extraction kit (Qiagen, CA). The purified DNA samples were sent for sequencing to Eurofins MWG Operon (Huntsville, AL). Initially, we sequenced only one strand of each product, but when base calls were dubious, the second strand was also sequenced for comparison. Partial sequences obtained were submitted for BLAST analysis (Altschul et al., 1990) to determine similarities with other spotted fever group rickettsia species.

\section{Molecular tick identification}

As taxonomic keys are not available for most immature exotic tick species, a fragment of the mitochondrial 12S rDNA gene sequence was amplified from 91 tick DNA samples with primers T1B and T2A (Beati and Keirans, 2001; Labruna et al., 2009; Beati et al., 2012) obtained from Life Technologies (Grand Island, NY). A MasterTaq Kit from 5-PRIME (Gaithersburg, MD) was used to amplify tick DNA. The amplicons were sent to the HighThroughput Genomics Center at Washington University for bidirectional sequencing. The complementary strands were assembled with Sequencher 4.5 (Gene Codes Corporation, Ann Arbor, MI) and submitted to GenBank. The sequences were compared to homologous nucleotide fragments in GenBank by using BLAST (http://blast.ncbi.nlm.nih.gov/; Altschul et al., 1990). Although interspecific cut-off divergence levels in mitochondrial ribosomal genes have not been determined for each genus of ticks, published data show that $3 \%$ sequence divergence or less are consistent with conspecificity in most of the earlier radiating genera in hard-tick evolution (Ixodes, Amblyomma, and Haemaphysalis) (Norris et al., 1996; Beati and Keirans, 2001; Mixon et al., 2006; Casati et al., 2008; Labruna et al., 2009; Beati et al., 2012). Therefore, for this study, we will consider that sequences with over $97 \%$ similarity belong to the same species.

\section{Phylogenetic analysis of rickettsial relationships}

Sequences were manually aligned with McClade 4.07 (Sinauer Associates, Sunderland, MA) (Maddison and Maddison, 2000) by considering the codon reading frame. Sequences were considered to be distinct when they differed by at least one base pair (indels included). The data set was analyzed by Bayesian analysis with MrBayes 2.01 (Huelsenbeck and Ronquist, 2001). Two runs, with 4 chains each, were processed simultaneously for Bayesian analysis $(1,000,000$ generations). Trees were sampled at every 100th iteration. Trees saved before the average standard deviation of split fragments converged to a value of less than 0.01 were discarded from the final sample series. The 50\% majority-rule consensus tree of the remaining trees was inferred, and posterior probabilities were recorded for each branch. 
Maximum likelihood distances were calculated in PAUP 4.10b (Swofford, 2002) after the model best fitting the data was evaluated in ModelTest 3.7 (Posada and Crandall, 1998). Sequences of other published rickettsial reference strains were included in the analysis for comparison: Rickettsia amblyommii (AY062007 and GQ891955), Rickettsia raoultii (DQ365801S1), Rickettsia “argentinae” (EU8265130), Rickettsia parkeri (RPU43802), Rickettsia africae (RAU43790), Rickettsia sibirica (RSU43807), Rickettsia conorii (RCU43806), endosymbiont of Amblyomma tuberculatum (JF934878), Rickettsia slovaca (RSU43808), Rickettsia rickettsii (RRU43804), Rickettsia honei (AF018075), Rickettsia japonica (RJU43795), Rickettsia massiliae (RMU43799), Rickettsia rhipicephali (U43803), Rickettsia aeschlimannii (RMU43800), Rickettsia montanensis (U43801), Rickettsia monacensis (DQ100169S1), endosymbiont of Amblyomma dubitatum (JN676159), Candidatus Rickettsia colombianensis (JF905458), and Rickettsia australis (AF149108). The sequences of $R$. australis, $R$. monacensis, $R$. montanensis, Candidatus R. colombiensis, and endosymbiont of $A$. dubitatum were used as outgroups.

\section{Nucleotide sequence accession numbers}

The rickettsial sequences obtained from the DNA extracted from tick samples were assigned GenBank accession numbers: JQ690558, JQ690561, JQ690567, JQ690569, JQ690572, JQ690573, JQ690575, JQ690577-JQ690595, JQ690597, JQ690598, JQ690600-JQ690606, JQ690608-JQ690621, JQ690623-JQ690644. The rickettsial sequences obtained from the DNA extracted from migratory songbird samples were assigned GenBank accession numbers: JQ695855-JQ695859 and JQ658435-JQ658449. Tick sequence GenBank accession number: KF195929

\section{Results}

Sampling

Of 6039 birds that were captured at the study site near Johnson Bayou, Louisiana, during the 2009 and 2010 migration sessions, 2064 (34\%) were examined for ticks. Blood samples were taken from 252 birds (12\%) to test for spotted fever group rickettsiae. A total of 272 ticks was found attached to 49 (2.4\%) birds, and 91 of the ticks were successfully removed from 35 individual birds for further analysis. All collected ticks were identified first to developmental stage and then to species level. All ticks were either larvae (70\%) or nymphs (30\%), and no adult ticks were found. Ticks were removed from the eyes (24\%), bill (18\%), nape (16\%), crown (12\%), cloaca (10\%), throat (8\%), and from the mantle (6\%) of birds, with the remaining $6 \%$ distributed throughout the body (Fig. 1). Immature ticks were found on 23 different passerine species: Twelve of the birds were assigned to the canopy/subcanopy group, 4 to the understory group, and 7 to the ground group (Supplementary Table 1). Most ticks were attached to birds in the ground foraging cohorts (184 ticks on 22 individuals), followed by the canopy group (34 ticks on 17 birds), and the understory group (54 ticks on 10 birds). Of the birds with attached ticks, the ground cohort had the lowest mean tick burden (1.2) while the canopy cohort had the highest (2.0). The understory birds had a mean of 1.7 ticks per bird. No immature ticks were found in the vegetation at the study site by the routine drag-cloth method.

\section{Tick identification}

All collected ticks were identified to either genus or species level (Fig. 2). Of the 91 sequences obtained, 17 (19\%) were 100\% identical to sequence AY225321 of Amblyomma nodosum, 11 (12\%) were 99\% similar to sequence AY225322 of Amblyomma calcaratum, $22(24 \%)$ were $98-99 \%$ similar to several sequences of A. longirostre (EU805562, EU805561, AY342264, EU805558, EU805559, and EU805557 in Labruna et al., 2009), 1 (1\%) was 99\% similar to Haemaphysalis leporispalustris (AM410574), 38 (42\%) were 99\% 
similar to Haemaphysalis juxtakochi (KF195929), and 2 (2\%) were 99\% similar to both, Amblyomma maculatum (AY342285) and Amblyomma triste (AY342286). This is not surprising when knowing that the taxonomic status of A. maculatum and A. triste is under scrutiny, and recent findings indicate that the 2 taxa may have to be synonymized (Beati, unpublished data). For each tick species, sequences were identical.

\section{Spotted fever group rickettsiae identification}

We determined the prevalence of spotted fever group Rickettsia spp. infection in collected ticks and songbird blood samples using ompA gene-specific primers in a nested PCR (Fig. 3). Of the 91 ticks collected from 35 birds, 71 (78\%) were positive for spotted fever group Rickettsia spp. (Supplementary Table 1). The sequences were aligned and after adjusting for differences in sequence length, the matrix was 486 bp long. The AIC model best fitting the data in ModelTest was the TVM+G, and the divergence values listed below were calculated in PUAP based on this model. The phylogenetic reconstruction shows that the detected rickettsial strains belong to 3 main clades: Candidatus Rickettsia amblyommii, Rickettsia sp. "Argentina", and a possibly novel genotype represented by sequences LON43A and NOD5B (Fig. 4). We found 2 unique sequences: Rickettsia endosymbiont of Amblyomma longirostre isolate 43A (GenBank accession no. JQ690610) (LON43A) from A. longirostre and Rickettsia endosymbiont of Amblyomma nodosum isolate 31B from A. nodosum (GenBank accession no. JQ690602) (NOD31B). The closest relative $(0.2 \%$ maximum likelihood divergence) of LON43A was Rickettsia endosymbiont of Amblyomma nodosum isolate 5B (GenBank accession no. JQ690561) (NOD5B), which represented 26 identical sequences in the phylogenetic reconstruction. Among the 26 identical sequences, 10 were detected in A. nodosum, 8 in A. calcaratum, 7 in A. longirostre, and 1 in Haemaphysalis spp. Among the reference strains, $R$. africae, $R$. parkeri, $R$. slovaca, and $R$. sibirica were the closest relatives of LON43 and NOD5B with divergence values between 2.50 and $3.41 \%$. As the reference strains themselves can diverge from each other by 1.65 to $1.88 \%$, it is likely that NOD5B and LON43 constitute a yet undescribed novel rickettsial genotype. Rickettsia amblyommii isolate 15B (GenBank accession no. JQ690575) (Ambly15B) from Haemaphyslais juxtakochi and Rickettsia amblyommii isolate 17B (GenBank accession no. JQ690578) (Ambly17B) from A. nodosum were identical and were represented by Ambly15B in the phylogenetic tree. These sequences were very similar ( $0.63 \%$ divergence $)$ to Candidatus Rickettsia amblyommii isolate 23B (GenBank accession no. JQ690590) (AMBLY23B) and Candidatus R. amblyommii ( $0.22 \%)$. Ambly23B represents 28 identical sequences (7 in A. longirostre and 21 in Haemaphysalis spp.), also diverging by only 0.91 to $0.93 \%$ from Candidatus R. amblyommii strains. This group also included sequences identical to the so-called Aranha strain (Labruna et al., 2004). Therefore, we can assume that Ambly15B and Ambly23B all belong to the R. amblyommii genotype. Rickettsia endosymbiont of Amblyomma maculatum isolate 10B (GenBank accession no. JQ690567) (MAC10B) represented 13 identical sequences (1 from A. nodosum, 1 from A. calcaratum, 1 from A. maculatum, and 10 from Haemaphysalis spp.), which were identical to Rickettsia sp. "Argentina" and to the endosymbiont of Amblyomma maculatum (Sumner et al., 2007; Tomassone et al., 2010). Of the 20 rickettsial strains detected in the bird blood, 18 were identical to Rickettsia sp. "Argentina" and to the endosymbiont of Amblyomma maculatum (Sumner et al., 2007; Tomassone et al., 2010), and one differed from them by only 2 base pairs (JQ695857), while the quality of the sequence from WOTH16853 was too bad for comparison. The NOD31B sequence differed only by $0.2 \%$ from MAC10B. Of the 91 ticks, 54 were infected with rickettsial strains and were found on infected birds, 14 were not infected and were found on infected birds, 18 were infected, but found on noninfected birds, and 6 were not infected and were found on noninfected birds. Only in 5 cases, such as Rickettsia endosymbiont of Amblyomma calcaratum isolate 11B (GenBank accession no. JQ690569) (CAL11B), Rickettsia endosymbiont of Haemaphysalis juxtakochi isolate 20B 
(GenBank accession no. JQ690584) (HAE20B), Rickettsia endosymbiont of Amblyomma nodosum isolate 26A (GenBank accession no. JQ690593) (NOD26A), Rickettsia endosymbiont of Haemaphysalis juxtakochi isolate 28B (GenBank accession no. JQ690597) (HAE28B), and Rickettsia endosymbiont of Amblyomma nodosum isolate 31B (GenBank accession no. JQ690602) (NOD31B), the rickettsia found in the tick from a given bird was the same as that detected in that bird, while in 49 cases the rickettsia detected in the ticks did not correspond to the strain from the bird.

\section{Discussion}

All birds sampled in this study were intercontinental migrants that winter in the Caribbean Basin, Mexico, and/or Central and South America. Within hours prior to sampling, they had engaged in a non-stop flight of 18-24 hours across the Gulf of Mexico. In this study, we observed an overall rate of bird infestation by ticks of 3\%, a value similar to other previously reported findings (Kinsey et al., 2000). Nevertheless, the value was highly variable when comparing bird species. Because the H. juxtakochi and Amblyomma ticks quest or ambush their host in the vegetation, it is not surprising to find more ticks on the ground-dwelling birds (Comstedt et al., 2006; James et al., 2011). The tick infestation density observed in this study may underestimate the number of ticks attached to birds at their first resting place after the trans-Gulf migration due to ticks may have been lost during the long flight over the ocean, but also because of bird handling constraints which do not always allow a thorough examination of birds. Since all of the ticks removed were partially engorged, it is likely that the ticks had been acquired while foraging in tropical locations shortly before the beginning of migration. Moreover, the fact that no ticks could be collected from the study site on the vegetation further supports a foreign origin for all these ticks. Of the ticks identified in this study, only 3 (A. maculatum and H. leporispalustris) out of 91 could have been local Mississippi ticks, while all other ticks were of neotropical origin. Although interspecific cut-off similarity values in tick $12 \mathrm{~S}$ rDNA sequences have yet to be determined and may vary among tick genera, there is no doubt that similarity values over 99\% in mitochondrial ribosomal gene sequences indicate cospecificity (Norris et al., 1996; Beati and Keirans, 2001; Mixon et al., 2006; Casati et al., 2008; Beati et al., 2012).

Therefore, we can confidently state that at least $90 \%$ of the ticks collected on our birds were exotic and originated from the wintering areas of Nearctic-Neotropical songbird migrants. As the exotic tick species identified in this study have never been collected on anything other than migratory birds in the United States (Keirans and Durden, 2001), it is very likely that once in North America, they have not managed to establish themselves or disseminate further. Their inability to colonize northern latitudes is certainly due to the fact that most of these exotic ticks are exclusive in the choice of their adult vertebrate hosts, which in the case of A. longirostre, A. nodosum, and A. calcaratum are species that do not occur in the United States (Guglielmone et al., 2003). However, were ecological conditions to change, adult $H$. juxtakochi can feed on deer (Guglielmone et al., 2003) and would find an ample food source in the United States. Although it is unlikely that Neotropical ticks can presently develop in the United States, drag-cloth collections should be pursued through the years, and particularly after the northbound migration is over, to verify whether or not some of these ticks manage to molt and quest in subsequent months.

The migratory birds infected with tick-borne spotted fever group rickettsiae represented 13 phylogenetically diverse passerine species characterized by varied breeding and wintering ranges. All birds were infected with the same group of rickettsia, corresponding to the recently described Rickettsia sp. "Argentina" (Tomassone et al., 2010) and to an endosymbiont from A. maculatum (Sumner et al., 2007). The ticks were, however, infected with a number of different rickettsial genotypes which rarely matched the rickettsial genotype found in the birds (when birds were infected). When rickettsiae are detected in 
engorged ticks, it may mean that either the tick is the vector of the bacteria or that the tick is just carrying whichever organism was present in the vertebrate host. In this case, we have rickettsia-negative ticks from rickettsia-positive birds, and rickettsia-positive ticks from birds infected with a different rickettsia than that found in the tick. This may indicate that the Argentine rickettsial clade has a particular affinity for birds and that the other rickettsial strains detected in ticks are unable to infect avian hosts. Interestingly, the bird-infecting clade of rickettsia was encountered in A. nodosum, A. calcaratum, and H. juxtakochi while it was not found in $A$. longirostre, a tick that favors birds as host for its immature stages (Aragao, 1936; Labruna et al., 2007a, 2007b, 2009; Nava et al., 2010; Ogrzewalska et al., 2010). The lack of rickettsial infection in some birds that were infested with infected ticks suggests that either the rickettsial strains in the ticks have no affinity to birds and cannot infect them or that the time elapsed since the beginning of feeding for some of these ticks was not sufficient to effectively infect birds (Hildebrandt et al., 2010). Rickettsial transmission usually requires a minimum of 12-24 h (Jongejan and Uilenberg, 2004; Bowman and Sauer, 2004). The latter explanation, however, is less appealing as ticks infesting birds are active for long periods in the Neotropics, not just at the beginning of bird northbound migration. Birds are usually repeatedly infested in the Neotropics by immatures of all these ticks. Given the rickettsial prevalence in the ticks, it is unlikely that they would not become infected by other rickettsial genotypes, through repeated infestations.

Alternatively, repeated infections in birds may elicit a strong immune response against some but not all rickettsiae in birds. Although our data confirm an overall lack of a rickettsia-tickspecific relationship, these observation may spur further investigation in the specific relationships between birds, bird immune response, and rickettsiae. It has been proposed that some of the cases of rickettsiosis reported as Rocky Mountain spotted fever (caused by Rickettsia rickettsii) in the United States may have been caused by $R$. amblyommii (Billeter et al., 2007; Apperson et al., 2008). Rickettsia amblyommii has been identified from A. americanum ticks in the United States (Burgdorfer et al., 1981; Goddard and Norment, 1986; Weller et al., 1998; Jiang et al., 2010) and from a number of Neotropical ticks (Hun et al., 2011; Bermudez et al., 2012; Pacheco et al., 2012; Saraiva et al., 2013). The possible pathogenic effects for humans of Rickettsia sp. "Argentina" and of the rickettsia first detected in this study are not known. In order to fully characterize the new rickettsia, additional rickettsial gene sequences should be obtained and the strain should be isolated in cell culture. In conclusion, although several studies have shown that migratory birds can carry exotic tick species to the United States (Jones et al., 1972; Alekseev et al., 2001; Bjöersdorff et al., 2001; Scott et al., 2001; Keirans and Durden, 2001), this is the first report showing that fairly large numbers of tropical ticks have frequent access to mainland United States. The high level of rickettsial prevalence in these ticks indicates that birds can import known and novel rickettsial strains from the tropics on a regular basis. Rickettsia amblyommii and the Rickettsia sp. "Argentina" have already shown to be established in both South and North America, although we do not know if they dispersed northwards from South to North America or southwards. Whether or not the novel rickettsial genotype identified in this study will be able to establish itself in the United States will depend on its ability to switch to local vector species and on the availability of suitable reservoir hosts. Many rickettsial species that had been described as being nonpathogenic have later been found to be pathogenic for humans (Pretorius and Birtles, 2002; Paddock et al., 2004; Whitman et al., 2007; Sumner et al., 2007; Apperson et al., 2008). It is, therefore, important to keep an updated inventory of all the different rickettsial genotypes circulating in nature, as they may turn out to be of public health interest.

\section{Supplementary Material}

Refer to Web version on PubMed Central for supplementary material. 


\section{Acknowledgments}

This work was partly supported by Pakistan-US Science and Technology Cooperation program (US DOS Award PGA-P21049) to SK, the National Science Foundation award (0078189, FRM), and the National Science Foundation grant \#1026146 to L. Beati. We thank MS-INBRE core facility supported by NIH-NIGMS (P20 GM103476).

\section{References}

Alekseev A, Dubinina H. Bloodsucking arthropods: the danger for travellers and hazard of vector travelling. Wiad Parazytol. 2001; 47:33-37. [PubMed: 16888948]

Altschul SF, Gish W, Miller W, Myers EW, Lipman DJ. Basic local alignment search tool. J Mol Biol. 1990; 215:403-410. [PubMed: 2231712]

Anderson JF, Johnson RC, Magnarelli LA, Hyde FW. Involvement of birds in the epidemiology of the Lyme disease agent Borrelia burgdorferi. Infect Immun. 1986; 51:394-396. [PubMed: 3943893]

Apperson CS, Engber B, Nicholson WL, Mead DG, Engel J, Yabsley MJ, Dail K, Johnson J, Watson DW. Tick-borne disease in North Carolina: Is "Rickettsia amblyommii" a possible cause of rickettsiosis reported as Rocky Mountain spotted fever? Vector Borne Zoonotic Dis. 2008; 8:597606. [PubMed: 18447622]

Aragao HB. Ixodidas brasileiros e de alguns paises limitrophes. Mem Inst Oswaldo Cruz. 1936; 31:759-843.

Barros-Battesti, DM.; Arzua, M.; Bechara, GH. Carrapatos de importanicia medico-veterinaria da Regiao Neotropical: Um guia ilustrado para identificacao de species, Sai Paulo. Vox/International Consortium on Ticks and Tick-borne Disease (ICTTD-3); Butantan, Brazil. 2006.

Barrow WC, Chen CC, Hamilton RB, Ouchley K, Spengler TJ. Disruption and restoration of en-route habitat, a case study: The Chenier Plain. Studies in Avian Biology. 2000; 20:71-87.

Beati L, Keirans JE. Analysis of the systematic relationships among ticks of the genera Rhipicephalus and Boophilus (Acari: Ixodidae) based on mitochondrial 12S ribosomal DNA gene sequences and morphological characters. J Parasitol. 2001; 87:32-48. [PubMed: 11227901]

Beati L, Patel J, Lucas-Williams H, Adakal H, Kanduma EG, Tembo-Mwase E, Krecek R, Mertins JW, Alfred JT, Kelly S, Kelly P. Phylogeography and demographic history of Amblyomma variegatum (Fabricius) (Acari: Ixodidae), the tropical bont tick. Vector Borne Zoonotic Dis. 2012; 12:514-525. [PubMed: 22448720]

Bermúdez S, Miranda R, Zaldívar Y, González P, Berguido G, Trejos D, Pascale JM, Labruna M. Detection of Rickettsia in ectoparasites of wild and domestic mammals from the Cerro Chucanti private reserve and from neighboring towns, Panamá, 2007-2010. Biomedica. 2012; 32:189-195. [PubMed: 23242292]

Billeter SA, Blanton HL, Little SE, Levy MG, Breitschwerdt EB. Detection of Rickettsia amblyommii in association with a tick bite rash. Vector Borne Zoonotic Dis. 2007; 7:607-610. [PubMed: 18052716]

Bjöersdorff A, Bergström EB, Massung RF, Haemig PD, Olsen B. Ehrlichia-infected ticks on migrating birds. Emerg Infect Dis. 2001; 7:877-879. [PubMed: 11747702]

Blair PJ, Jiang J, Schoeler GB, Moron C, Anaya E, Cespedes M, Cruz C, Felices V, Geuvara C, Mendoza L, Villaseca P, Sumner JW, Richards AL, Olson JC. Characterization of spotted fever group rickettsiae in fleas and tick specimens from northern Peru. J Clin Microbiol. 2004; 42:49614967. [PubMed: 15528680]

Bowman AS, Sauer JR. Tick salivary glands: function, physiology and future. Parasitology. 2004; 129:S67-S81. [PubMed: 15938505]

Burgdorfer W, Brinton LP. Mechanisms of transovarial infection of spotted fever rickettsiae in ticks. Ann N Y Acad Sci. 1975; 266:61-72. [PubMed: 829476]

Burgdorfer, W.; Hayes, SF.; Thomas, LA.; Lancaster, JL. A new spotted fever group rickettsia from the lone star tick, Amblyomma americanum. In: Burgdorfer, W.; Anacker, RL., editors. Rickettsiae and Rickettsial Diseases. Academic; New York: 1981. p. 595-602. 
Casati S, Bernasconi MV, Gern L, Piffaretti JC. Assessment of intraspecific mtDNA variability of European Ixodes ricinus sensu stricto (Acari: Ixodidae). Infect Genet Evol. 2008; 8:152-158. [PubMed: 18206426]

Clifford CM, Anastos G, Elbl A. The larval ixodid ticks of the eastern United States (AcarinaIxodidae). Misc Pub Entomol Soc Am. 1961; 2:213-237.

Comstedt P, Bergström S, Olsen B, Garpmo U, Marjavaara L, Mejlon H, Barbour AG, Bunikis J. Migratory passerine birds as reservoirs of Lyme borreliosis in Europe. Emerg Infect Dis. 2006; 12:1087-1095. [PubMed: 16836825]

Cooley RA. The genera Boophilus, Rhipicephalus, and Haemaphysalis (Ixodidae) of the New World. Natl Inst Health Bull. 1946; 187:54.

Elfving K, Olsen B, Bergström S, Waldenström J, Lundkvist A, Sjöstedt A, Mejlon H, Nilsson K. Dissemination of spotted fever rickettsia agents in Europe by migrating birds. PLoS ONE. 2010; 5:e8572. [PubMed: 20052286]

Falco RC, Fish D. Prevalence of Ixodes dammini near the homes of Lyme disease patients in Westchester County, New York. Am J Epidemiol. 1988; 127:826-830. [PubMed: 3354547]

Goddard J, Norment BR. Spotted fever group rickettsiae in the lone star tick, Amblyomma americanum (Acari: Ixodidae). J Med Entomol. 1986; 23:465-472. [PubMed: 3772952]

Guglielmone, AA.; Estrada-Peña, A.; Keirans, JE.; Robbins, RG. Ticks (Acari: Ixodidae) of the Neotropical Zoogeographic Region. Atlanta Books; Houten, The Netherlands: 2003.

Guglielmone AA, Robbins RG, Apanaskevich DA, Petney TN, Estrada-Peña A, Horak IG, Shao R, Barker SC. The Argasidae, Ixodidae and Nuttalliellidae (Acari: Ixodida) of the world: a list of valid species names. Zootaxa. 2010; 2528:1-28.

Gregoire A, Faivre B, Heeb P, Cezilly F. A comparison of infestation patterns by Ixodes in urban and rural populations of the common blackbird Turdus merula. International Journal of Avian Science. 2002; 144:640-645.

Hasle G, Bjune GA, Midthjell L, Roed KH, Leinaas HP. Transport of Ixodes ricinus infected with Borrelia species to Norway by northward-migrating passerine birds. Ticks Tick-Borne Dis. 2011; 2:37-43. [PubMed: 21771535]

Helms CW, Drury WH. Winter and migratory weight and fat field studies on some North American buntings. Bird-Banding. 1960; 31:1-40.

Hildebrandt A, Franke J, Meier F, Sachse S, Dorn W, Straube E. The potential role of migratory birds in transmission cycles of Babesia spp., Anaplasma phagocytophilum, and Rickettsia spp. Ticks Tick-Borne Dis. 2010; 1:105-107. [PubMed: 21771516]

Hoogstraal H, Kaiser MN, Traylor MA, Gaber S, Guindy E. Ticks (Ixodoidea) on birds migrating from Africa to Europe and Asia. Bull Wld Hlth Org. 1961; 24:197-212.

Hoogstraal H, Kaiser MN, Traylor MA, Guindy E, Gaber S. Ticks (Ixodoidea) on birds migrating from Africa to Europe and Asia. Bull Wld Hlth Org. 1963; 28:235-262.

Hubalek Z. An annotated checklist of pathogenic microorganisms associated with migratory birds. J Wildl Dis. 2004; 40:639-659. [PubMed: 15650082]

Huelsenbeck J, Ronquist F. MrBayes: Bayesian inference of phylogenetic trees. Bioinformatics. 2001; 17:754-755. [PubMed: 11524383]

Hun L, Troyo A, Taylor L, Barbieri AM, Labruna MB. First report of the isolation and molecular characterization of Rickettsia amblyommii and Rickettsia felis in Central America. Vector Borne Zoonotic Dis. 2011; 11:1395-1397. [PubMed: 21612539]

James MC, Furness RW, Bowman AS, Forbes KJ, Gilbert L. The importance of passerine birds as tick hosts and in the transmission of Borrelia burgdorferi, the agent of Lyme disease: a case study from Scotland. The International Journal of Avian Science. 2011; 153:293-302.

Jiang J, Yarina TM, Miller K, Stromdahl EY, Richards AL. Molecular detection of Rickettsia amblyommii in Amblyomma americanum parasitizing humans. Vector Borne Zoonotic Dis. 2010; 10:329-340. [PubMed: 19877809]

Jones EK, Clifford CM, Keirans JE, Kohls GM. The ticks of Venezuela (Acarina: Ixodidae) with a key to the species of Amblyomma in the Western hemisphere. Brigham Young Univ Sci Bull Biol Ser. $1972 ; 17: 1-40$.

Jongejan F, Uilenberg G. The global importance of ticks. Parasitology. 2004; 129:3-14. 
Keirans JE, Durden LA. Illustrated key to nymphs of the tick genus Amblyomma (Acari: Ixodidae) found in the United States. J Med Entomol. 1998; 35:489-495. [PubMed: 9701933]

Keirans JE, Durden LA. Invasion: exotic ticks (Acari: Argasidae, Ixodidae) imported into the United States. A review and new records. J Med Entomol. 2001; 38:850-861. [PubMed: 11761384]

Kinsey AA, Durden LA, Oliver JH. Tick infestations of birds in coastal Georgia and Alabama. J Parasitol. 2000; 86:251-254. [PubMed: 10780541]

Labruna MB, McBride JW, Bouyer DH, Camargo LMA, Camargo EP, Walker DH. Molecular evidence for a spotted fever group Rickettsia species in the tick Amblyomma longirostre in Brazil. J Med Entomol. 2004; 41:533-537. [PubMed: 15185961]

Labruna MB, Sanfilippo LF, Demetrio C, Menezes AC, Pinter A, Guglielmone AA, Silveira LF. Ticks collected from birds in the state of Sao Paulo, Brazil. Exp Appl Acarol. 2007a; 43:147-160. [PubMed: 17882514]

Labruna MB, Pacheco RC, Nava S, Richtzenhain LJ, Guglielmone AA. Infection by Rickettsia bellii and Candidatus Rickettsia amblyommii in Amblyomma neumanni ticks from Argentina. Microb Ecol. 2007b; 54:126-133. [PubMed: 17264991]

Labruna MB, Onofrio VC, Beati L, Arzua M, Bertola PB, Ribeiro AF, Barros-Battesti DM. Redescription of the female, description of the male, and several new records of Amblyomma parkeri (Acari: Ixodidae), a South American tick species. Exp Appl Acarol. 2009; 49:243-260. [PubMed: 19241123]

Morshed MG, Scott JD, Fernando K, Beati L, Mazerolle DF, Geddes G, Durden LA. Migratory songbirds disperse ticks across Canada, and first isolation of the Lyme disease spirochete, Borrelia burgdorferi, from the avian tick, Ixodes auritulus. Journal of Parasitology. 2005; 91:780-790. [PubMed: 17089744]

Maddison, DR.; Maddison, WP. MacClade 4: Analysis of phylogeny and character evolution Vs. 4.05. Sinauer Associates, Inc; Sunderland, MA: 2000.

Moore, FR. Cheniers of Louisiana and the stopover ecology of migrant landbirds. In: Able, KP., editor. A Gathering of Angels: Ecology and Conservation of Migrating Birds. Cornell University Press; Ithaca, NY: 1999.

Movila A, Dubinina HV, Tolstenkov OO, Toderas I, Alekseev AN. Detection of Babesia Sp. EU1 and members of spotted fever group rickettsiae in ticks collected from migratory birds at Curonian Spit, North-Western Russia. Vector-Borne Zoonotic Dis. 2010; 10:1-3.

Mixon TR, Lydy SL, Dasch GA, Real LA. Inferring the population structure and demogrpahic history of the tick, Amblyomma americanum Linnaeus. J Vector Ecol. 2006; 31:181-192. [PubMed: 16859107]

Nava S, Velazco PM, Gugliemone AA. First record of Amblyomma longirostre (Koch 1844) (Acari: Ixodidae) from Peru, with a review of this tick's host relationships. Syst Appl Acarol. 2010; 15:21-30.

Norris DE, Klompen JS, Keirans JE, Black WC. Population genetics of Ixodes scapularis (Acari: Ixodidae) based on mitochondrial 16S and 12S genes. J Med Entomol. 1996; 33:78-89. [PubMed: 8906909]

Ogrzewalska M, Uezu A, Labruna MB. Ticks (Acari: Ixodidae) infecting wild birds in the eastern Amazon, northern Brazil, with notes on rickettsial infection in ticks. Parasitol Res. 2010; 106:809816. [PubMed: 20140452]

Ogrzewalska M, Pacheco RC, Uezu A, Ferreira F, Labruna MB. Ticks (Acari: Ixodidae) infesting wild birds in an Atlantic Forest area in the state of Sao Paulo, Brazil, with isolation of Rickettsia from the tick Amblyomma longirostre. J Med Entomol. 2008; 45:770-774. [PubMed: 18714882]

Olsen B, Persson K, Broholm KA. PCR detection of Chlamydia psittaci in faecal samples from passerine birds in Sweden. Epidemiol Infect. 1998; 121:481-484. [PubMed: 9825803]

Olsén B, Jaenson TGT, Bergström S. Prevalence of Borrelia burgdorferi sensu lato-infected ticks on migrating birds. Appl Environ Microbiol. 1995; 61:3082-3087. [PubMed: 7487041]

Pacheco RC, Arzua M, Nieri-Bastos FA, Moraes-Filho J, Marcili A, Richtzenhain LJ, Barros-Battesti DM, Labruna MB. Rickettsial infection in ticks (Acari: Ixodidae) collected on birds in southern Brazil. J Med Entomol. 2012; 49:710-716. [PubMed: 22679880] 
Paddock CD, Sumner JW, Comer JA, Zaki SR, Goldsmith CS, Goddard J. Rickettsia parkeri: a newly recognized cause of spotted fever rickettsiosis in the United States. Clin Infect Dis. 2004; 38:805811. [PubMed: 14999622]

Posada D, Crandall KA. MODELTEST: testing the model of DNA substitution. Bioinformatics. 1998; 14:817-818. [PubMed: 9918953]

Pretorius AM, Birtles RJ. Rickettsia aeschlimannii: A new pathogenic spotted fever group Rickettsia, South Africa. Emerg Infect Dis. 2002; 8:874. [PubMed: 12141981]

Pyle, P. Identification guide to North American birds Part I. Bolinas, CA: Slate Creek Press; 1997.

Rappole, RH.; Morton, ES.; Lovejoy, TE.; Ruos, JL. Nearctic avian migrants in the Neotropics. Frant Royal, Virginia: Smithsonian Institution; 1995.

Roux V, Raoult D. Phylogenetic analysis of members of the genus Rickettsia using the gene encoding the outer membrane protein rOmpB (ompB). Int J Syst Evol Microbiol. 2000; 50:1449-1455. [PubMed: 10939649]

Roux V, Fournierm PE, Raoult D. Differentiation of spotted fever group rickettsiae by sequencing and analysis of restriction fragment length polymorphism of PCR-amplified DNA of the gene encoding the protein rOmpA. Journal of Clinical Microbiology. 1996; 34:2058-2065. [PubMed: 8862558]

Santos-Silva MM, Sousa R, Santos AS, Melo P, Encarnação V, Bacellar F. Ticks parasitizing wild birds in Portugal: detection of Rickettsia aeschlimannii, R. helvetica and R. massiliae. Exp Appl Acarol. 2006; 39:331-338. [PubMed: 16897568]

Saraiva DG, Nieri-Bastos FA, Horta MC, Soares HS, Nicola PA, Pereira LC, Labruna MB. Rickettsia amblyommii infecting Amblyomma auricularium ticks in Pernambuco, northeastern Brazil: Isolation, transovarial transmission, and transstadial perpetuation. Vector Borne Zoonotic Dis. 2013 Epub ahead of print.

Scott JD, Fernando K, Banerjee SN, Durden LA, Byrne SK, Banerjee M, Mann RB, Morshed MG. Birds disperse ixodid (Acari: Ixodidae) and Borrelia burgdorferi-infected ticks in Canada. J Med Entomol. 2001; 38:493-500. [PubMed: 11476328]

Sonenshine, DE. Biology of Ticks. Vol. 2. New York: Oxford University Press; 1993.

Sumner JW, Durden LA, Goddard J, Stromdahl EY, Clark KL, Reeves WK, Paddock CD. Gulf Coast ticks (Amblyomma maculatum) and Rickettsia parkeri, United States. Emerging Infect Dis. 2007; 13:751-753. [PubMed: 17553257]

Swofford, DL. PAUP* Phylogenetic Analysis Using Parsimony (*and other methods). Vs. 4.0b.10. Sinauer Associates, Inc; Sunderland, MA: 2002.

Tomassone L, Nuñez P, Ceballos LA, Gürtler RE, Kitron U, Farber M. Detection of “Candidatus Rickettsia sp. strain Argentina" and Rickettsia bellii in Amblyomma ticks (Acari: Ixodidae) from Northern Argentina. Exp Appl Acarol. 2010; 52:93-100. [PubMed: 20186466]

Weller SJ, Baldridge GD, Munderloh UG, Noda H, Simser J, Kurtti TJ. Phylogenetic placement of rickettsiae from the ticks Amblyomma americanum and Ixodes scapularis. J Clin Microbiol. 1998; 36:1305-1317. [PubMed: 9574696]

Whitman TJ, Richards AL, Paddock CD, Tamminga CL, Sniezek PJ, Jiang J. Rickettsia parkeri infection after tick bite, Virginia. Emerg Infect Dis. 2007; 13:334-336. [PubMed: 17479907] 


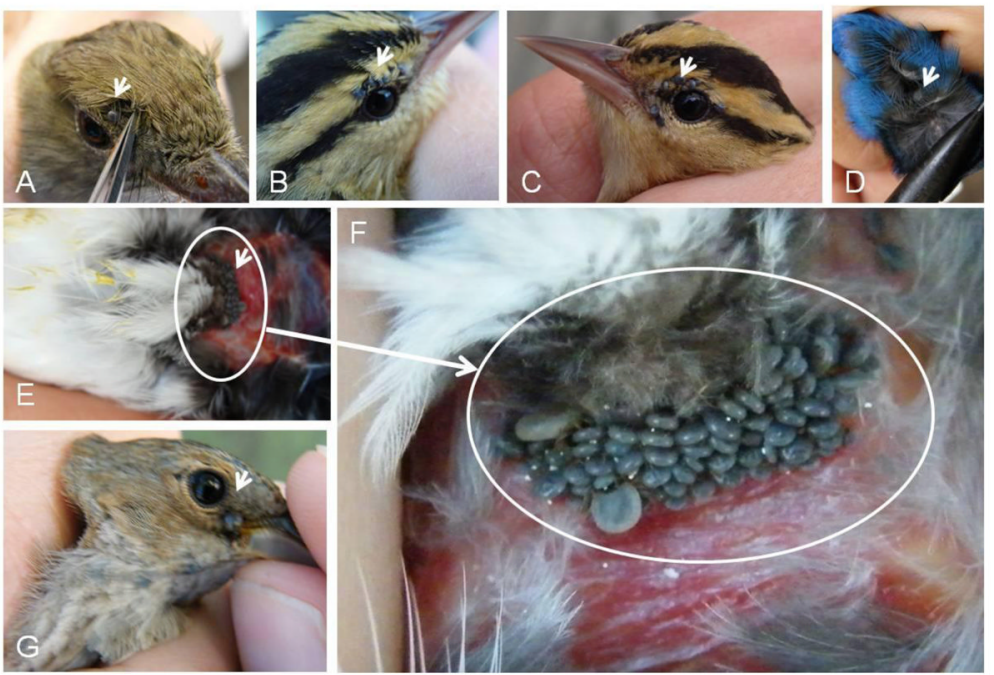

Fig 1.

Representative captured songbird species infested with immature ticks on various body parts during northward-bound migration at Johnson Bayou, Louisiana (2009-2010). (A) Tick on head of an Acadian flycatcher (Empidonax virescens). (B) Ticks attached to the upper eyelid of a worm-eating warbler (Helmitheros vermivorus). (C) Ticks attached on the left eye of a worm-eating warbler (H. vermivorus). (D) Tick embedded in feathers of an indigo bunting (Passerina cyanea). (E) Cloaca of a wood thrush (Hylocichla mustelina). (F) Ticks attached to the cloaca of a wood thrush (H. mustelina). (G) Partially fed tick attached to the right eye of an indigo bunting ( $P$. cyanea). 


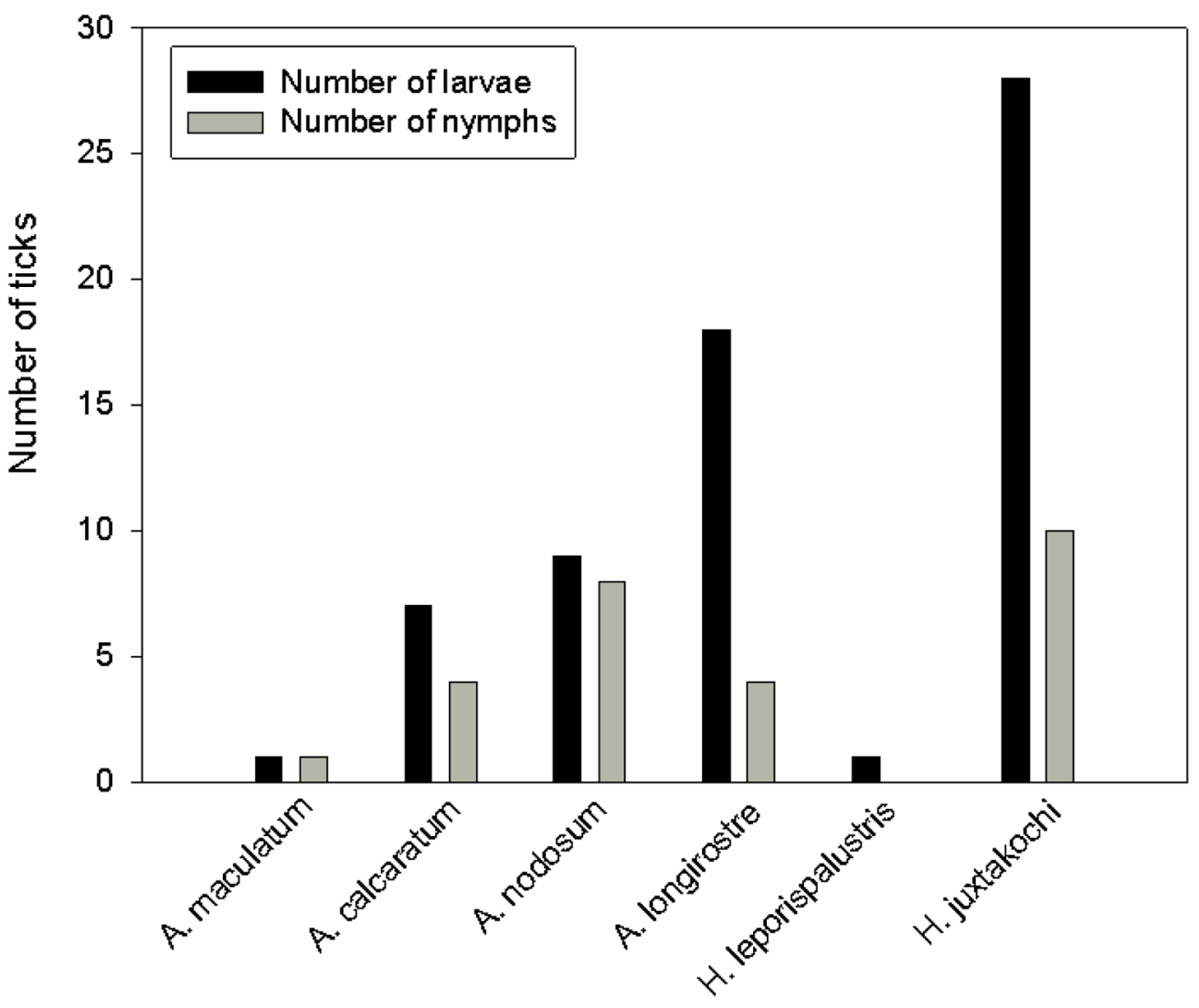

Fig 2.

Identified tick species collected from migratory songbirds. 

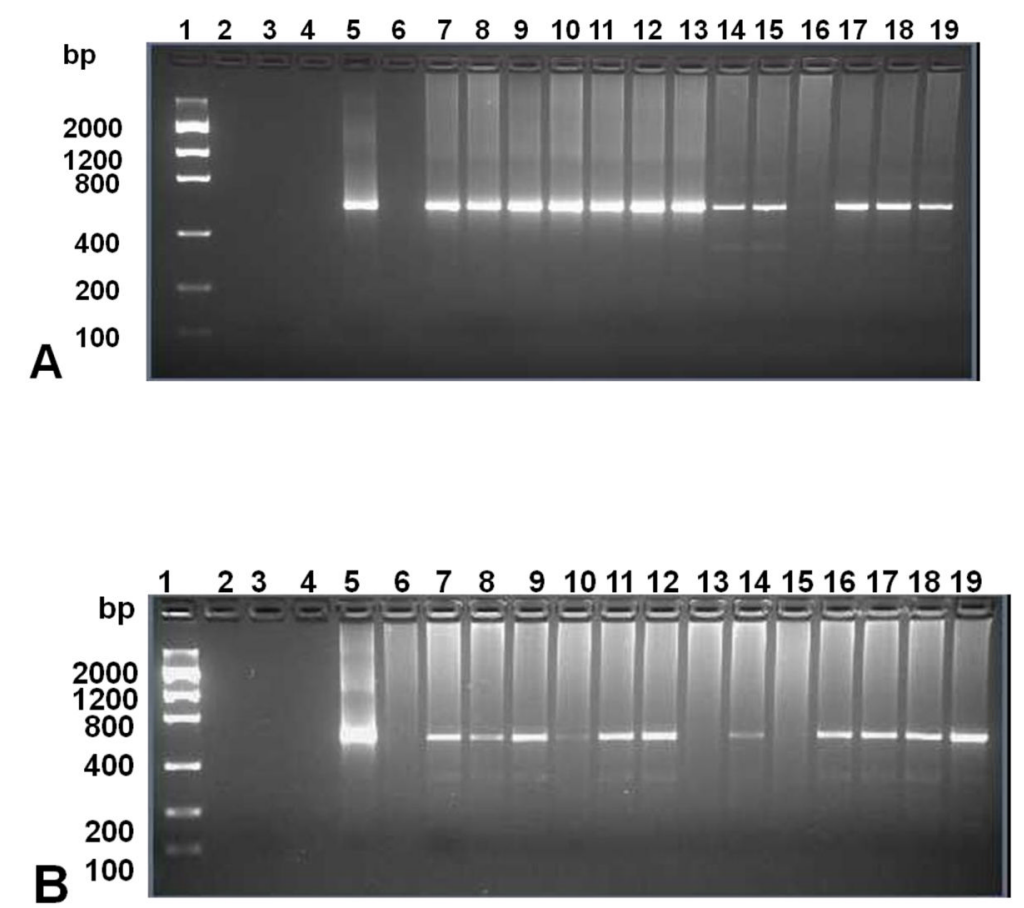

Fig 3.

(A) PCR amplification of spotted fever group Rickettsia spp. in exotic ticks collected from migratory birds. Lane 1: low DNA mass ladder; lanes 2, 4, 6: empty lanes; lane 3: notemplate control; lane 5: Rickettsia ompA-positive control; lanes 7-19: rickettsial ompA gene amplified from extracted tick DNA using gene-specific primers in a nested PCR assay. (B) PCR amplification of spotted fever group Rickettsia spp. in migratory songbird blood samples. Lane 1: low DNA mass ladder; lanes 2, 4: empty wells; lane 3: no-template control; lane 5: Rickettsia ompA-positive control, lanes 6-19: rickettsial ompA gene fragment amplified from extract bird blood DNA using gene-specific primers in a nested PCR assay. 


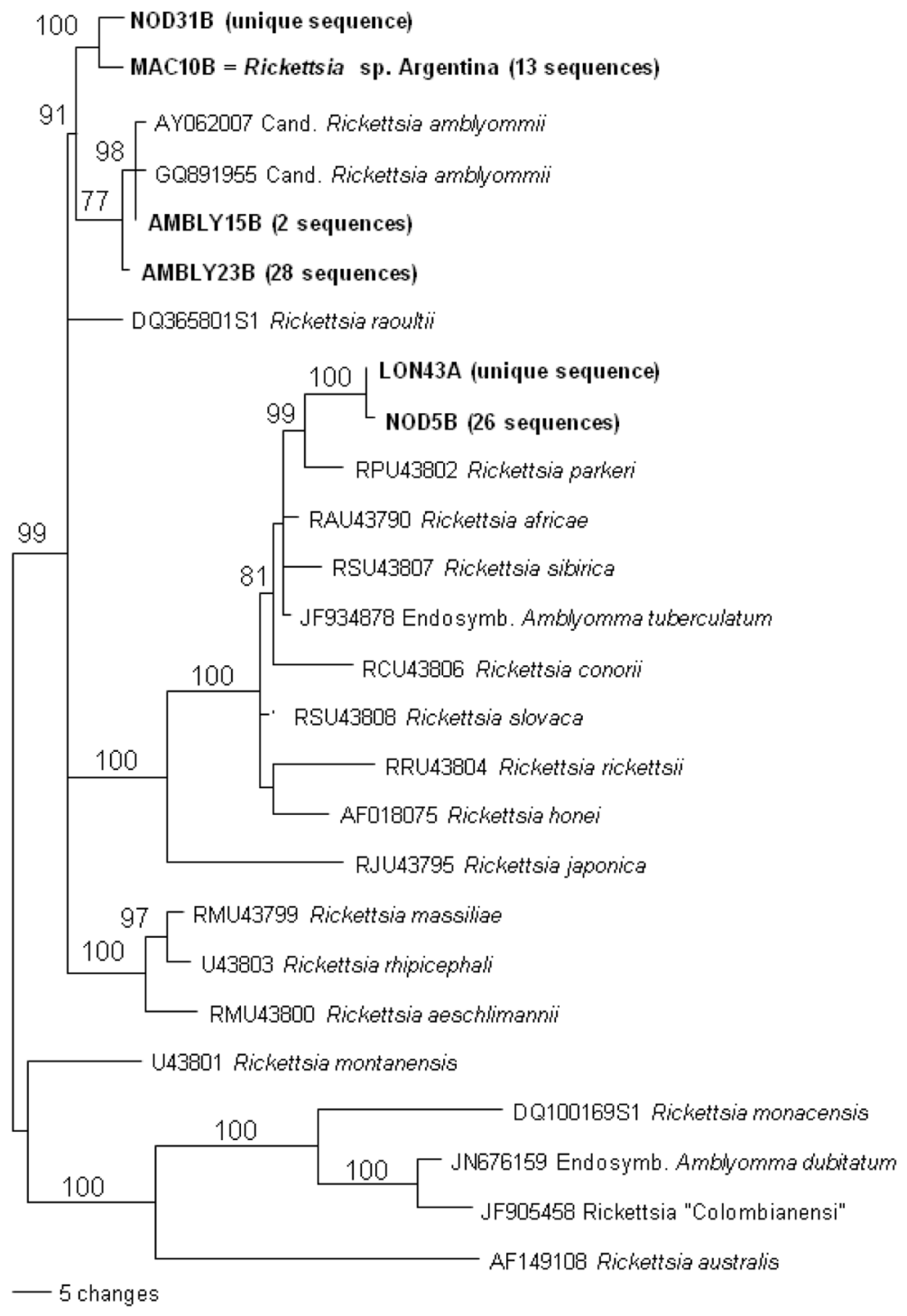

Fig 4.

Phylogenetic relationships of the rickettsial strains detected in ticks based on partial ompA gene sequences and inferred by Bayesian analysis. Number near nodes represents posterior probability support. 